\title{
СПЕЦИФИКА ПРОСТРАНСТВЕННО-СТРУКТУРНЫХ ИЗМЕНЕНИЙ И ЭФФЕКТИВНОСТЬ НОВЫХ ИНСТРУМЕНТОВ ЭКОНОМИЧЕСКОГО РАЗВИТИЯ РОССИЙСКОГО АААЬНЕГО ВОСТОКА'
}

\begin{abstract}
Аннотауия. Предмет. $B$ статье рассматривается спеиифика пространственноструктурных изменений в экономике российского Дальнего Востока. Проводится анализ созданных на территории макрорегиона инструментов социально-экономического развития. Џели: определение спеиифики пространственно-структурных изменений в экономике российского Дальнего Востока; анализ практики применения созданных инструментов соииально-экономического развития макрорегиона; выявление проблем, возникающих в ходе их реализации. Методология. Исследование базируется на историческом, диалектическом, абстрактно-логическом, расчетно-конструктивном и сравнительном методах научного познания. Результаты. Определена специфика пространственно-стоуктурных изменений в экономике российского Дальнего Востока. Проведен анализ созданных спеииальных институтов и механизмов развития макрорегиона. Выявлены основные проблемы, возникшие в ходе внедрения созданных инструментов развития макрорегиона, в частности: создание управленческих институтов, зачастую дублирующих друг друга; длительные плановые сроки получения земельного участка в силу сложных бюрократических проиедур; низкий уровень выполнения госпрограмм; наличие фактов масштабного хищения средств федерального бюджета. Выводы. За исследуемый период структура создаваемого ВРП в макрорегионе в разрезе входящих в него субъектов не претерпела значительных изменений. В динамике лишь усилилась зависимость региона от сырьевых отраслей экономики. Кроме того, практика применения разработанных инструментов развития Дальнего Востока характеризуется поддержкой проектов исключительно сьрьевой направленности. Таким образом, проводимая на Дальнем Востоке экономическая политика, при всех ее корректировках и нововведениях, скорее закрепляет, нежели видоизменяет сложившуюся отраслевую структуру экономики региона. Задачи увеличения объемов международных потоков отодвигают в проводимой политике задачи качественной и производственной модернизации экономики региона.
\end{abstract}

Ключевые слова: Социально-экономическое развитие, территории опережающего развития, валовый региональный продукт.

\section{SERIKOV STANISLA V GENNADIEVICH}

Senior Lecturer of the Department of "Finances" of FSBEI of HE "Amur State University", e-mail:stas.serikov@inbox.ru

\section{THE PARTICULARITIES OF SPATIAL-STRUCTURAL CHANGES AND EFFECTIVENESS OF NEW INSTRUMENTS OF ECONOMIC DEVELOPMENT OF THE RUSSIAN FAR EAST}

\begin{abstract}
Subject. The manuscript discusses the particularities of the spatial-structural changes in the economy of the Russian Far East. We are analyzing instruments of social-economic development created on the territory of the macroregion. The goals. Defining the particularities of spatial-structural changes in the economy of the Russian Far East. Analysis of the practice of using the created instruments of the social-economic development of the macroregion, finding the

\footnotetext{
${ }^{1}$ Исследование выполнено при финансовой поддержке РФФИ в рамках научного проекта № 18-010-00792 «Исследование факторов пространственной дифференциации ненаблюдаемой экономики, обеспечивающих сбалансированное развитие Дальнего Востока России».
} 
problems that arise in the process of their implementation. The methodology. The study is based on the historical, dialectical, abstract-logical, computational-constructive and comparative methods of scientific cognition. The results. We have determined the specifics of spatial-structural changes in the economy of the Russian Far East. We have analyzed the created special institutes and mechanisms of development of the macroregion. We have found the main problems that arose in the process of implementation of the created instruments of development of the macroregion, in particular: the creation of managerial institutes often duplicating each other; long-term planned deadlines of obtaining a land plot due to complex bureaucratic procedures; a low level of completion of state programs; the presence of facts of widespread theft of federal budget funds. The conclusions. Over the period researched, the structure of the created GD $\rho$ in the macroregion, in the context of the entities included in it did not sustain significant changes. In dynamics, the dependence of the region on raw material industries of the economy has only intensified. Besides, the practice of using the developed instruments of development of the Far East is characterized by support of projects specifically related to raw materials. Therefore, the economic policy used in the Far East, with all of its corrections and innovations, is more likely to be consolidating, other than modifying the established industry structure of the economy of the region. The tasks of increasing the volumes of international inflows supersede in the policy carried out the tasks of the high quality and industrial modernization of the economy of the region. According to our opinion, the process of integration of the Far East in the $A P R$ has to be accompanied by creating new markets for selling products. This will become possible due to offering new technology intensive products. The process of "a new product - a new industry - a new specialization of the region" has to be launched within the context of the created $\rho D A$. To achieve that, the government has to stimulate the development of high tech manufacturing and not allow incorporating $\rho D A$ in the already formed system of raw material economy. The trade-investment periphery built this way will contribute to the establishment of the Far East as one of the important players in the market of the $A \rho R$.

Keywords: Socio-economic development, territories of advanced development, gross regional product.

По нашему мнению, процесс интеграции Дальнего Востока в АТР должен сопровождаться созданием новых рынков сбыта продукции. Это станет возможным за счет предложения новых наукоемких продуктов. Процесс «новый продукт - новая отрасль - новая специализация региона» должен быть запущен в рамках созданных ТОР. Для этого государству следует стимулировать развитие высокотехнологичных производств и не допускать встраивания ТОР в уже сформированную систему сырьевой экономики. Выстроенная таким образом торговоинвестиционная периферия будет способствовать становлению Дальнего Востока в роли одного из значимых игроков на рынке АТР.

Российская экономика начала 2000 -х годов характеризовалась стремительным ростом. Это было связано с увеличением спроса на энергетические ресурсы и, как следствие, ростом мировых цен на энергоносители [18]. Основным потребителем данных ресурсов выступали быстроразвивающиеся новые индустриальные страны. Однако глобальный финансовый кризис, начавшийся в США в 2008 году, и украинский кризис 2014 года, вслед за которым были введены антироссийские санкции, снижение мировых цен на энергоносители, замедление темпов роста экономики Китая [19], приход к власти администрации Трампа, разворачивание новой политики протекционизма - все это стало серьезными вызовами для России. Сложившаяся конъюнктура оказала негативное влияние практически на каждый сектор российской экономики. Результатом этого явился отрицательный экономический рост 2015 и 2016 годов.

В сложившихся условиях ключевой государственной задачей для России стала выработка эффективных мер, направленных на восстановление экономики. Сырьевая ориентация российской экономики делает ее зависимой от волатильности мировых цен на энергоресурсы. Поэтому Правительством РФ был взят курс на совершенствование экономической структуры и поиск новых точек экономического роста.

С началом третьего срока правления В. В. Путина началось активное продвижение программы развития российского Дальнего Востока, принятие мер по укреплению связей России 

ЭКОНОМИЧЕСКОГО РАЗВИТИЯ РОССИЙСКОГО ДАЛЬНЕГО ВОСТОКА

со странами АТР. В связи с этим вопросы, касающиеся различных аспектов интеграции России в АТР, стали объектом исследования многих российских ученых, в частности, Л. Н. Гарусовой [2], В. Л. Ларина [7], А. П. Латкина [8], П. А. Минакира [10], Ж. В. Петруниной [12], О. В. Рензина [13], Ю. Д. Шмидта [17] и др.

Ориентация политики развития российского Дальнего Востока на Азиатско-Тихоокеанский регион обусловлена не только восстановлением традиционного для СССР военного присутствия в регионе, но и необходимостью включения макрорегиона в интеграционные процессы АТР, повышения уровня его социально-экономического развития, укрепления территориальной целостности страны, обеспечения экономики новыми двигателями роста. Россия граничит с рядом стран, расположенных в данном регионе, что дает ей возможность, используя свое геополитическое преимущество, стать ключевым игроком на Азиатско-Тихоокеанском пространстве [3].

Рассмотрим динамику ВРП по субъектам ДФО за период 2000-2016 годов (табл. 1).

ВРП в сопоставимых ценах по субъектам ДФО за 2000-2016 годы, млрд руб.

\begin{tabular}{|l|c|c|c|c|c|}
\hline \multicolumn{1}{|c|}{ Субъект РФ } & 2000 г. & 2004 г. & 2008 г. & 2012 г. & 2016 г. \\
\hline Дальневосточный федеральный округ & 224419,7 & 267427,9 & 327826,3 & 391859,6 & 431365,7 \\
\hline Республика Саха (Якутия) & 59564,2 & 60504,7 & 66108,8 & 78495,0 & 99739,9 \\
\hline Камчатский край & 13183,6 & 13851,1 & 16628,6 & 18476,1 & 22749,7 \\
\hline Приморский край & 45122,4 & 60033,4 & 67617,5 & 80841,6 & 84614,8 \\
\hline Хабаровский край & 47089,2 & 52555,7 & 57492,8 & 63513,6 & 73220,4 \\
\hline Амурская область & 19124,4 & 25325,9 & 28100,2 & 33266,3 & 33023,7 \\
\hline Магаданская область & 9454,6 & 9701,6 & 8982,1 & 11371,4 & 16870,4 \\
\hline Сахалинская область & 25274,0 & 36157,6 & 71248,4 & 93080,0 & 88169,0 \\
\hline Еврейская автономная область & 2750,0 & 4426,9 & 5121,6 & 6198,3 & 3986,7 \\
\hline Чукотский автономный округ & 2857,1 & 4871,1 & 6526,9 & 6617,4 & 7595,5 \\
\hline
\end{tabular}

Источник: рассчитано автором.

На протяжении всего исследуемого периода регионами-лидерами по созданию ВРП являются Республика Саха (Якутия), Сахалинская область, Приморский и Хабаровский края.

Рост экономик Республики Саха (Якутия) и Сахалинской области происходит за счет реализации крупных инвестиционных проектов. Основной приоритет отдается проектам топливно-энергетического комплекса и связанными с ними инфраструктурными проектами. Отраслью специализации экономик Хабаровского и Приморского краев является рыболовство. Для экономики Дальнего Востока эта отрасль является одним из магистральных направлений, развитию которой в последние годы государство уделяет особое внимание.

Среднерегиональный уровень ВРП наблюдается в Камчатском крае, Амурской и Магаданской областях. Регионами-аутсайдерами по данному показателю являются ЕАО и ЧАО.

Рассмотрим отраслевую структуру ВРП РФ и ДФО за период 2008-2016 годы (табл. 2).

Согласно данным табл. 2, в 2016 году на долю валового регионального продукта добывающей промышленности, связи и транспорта в экономике Дальнего Востока приходилось 41,4 $\%$, в экономике РФ - 21,4%. Следовательно, в динамике макрорегион только усиливает свою сырьевую направленность, не акцентируя внимания на развитии других отраслей.

Решению проблем социально-экономического развития российского Дальнего Востока уделяется внимание уже не одно десятилетие [15]. Общий перечень задач региональной экономической политики, сформулированный в «Стратегии социально-экономического развития Дальнего Востока и Байкальского региона на период до 2025 года» [5], по нашему мнению, сводится к следующему: 
Отраслевая структура ВРП РФ и ДФО за 2008-2016 годы, в \%.

\begin{tabular}{|l|c|c|c|c|c|c|}
\hline \multicolumn{1}{|c|}{ Вид деятельности } & \multicolumn{2}{|c|}{ РФ } & \multicolumn{2}{|c|}{ ДФО } & \\
\hline & 2008 & 2012 & 2016 & 2008 & 2012 & 2016 \\
\hline Сельское хозяйство, охота и лесное хозяйство & 4,6 & 4,2 & 5,1 & 3,7 & 3,3 & 3,4 \\
\hline Рыболовство, рыбоводство & 0,2 & 0,2 & 0,3 & 2,9 & 2,4 & 3,7 \\
\hline Добыча полезных ископаемых & 9,9 & 11,2 & 10,9 & 20,9 & 27,2 & 28,2 \\
\hline Обрабатывающие производства & 19,3 & 17,3 & 17,3 & 6,3 & 5,3 & 5,4 \\
\hline Производство и распределение электроэнергии, газа и воды & 3,5 & 3,8 & 3,9 & 4,0 & 3,9 & 4,2 \\
\hline Строительство & 6,9 & 7,2 & 6,3 & 10,7 & 9,8 & 6,7 \\
\hline $\begin{array}{l}\text { Оптовая и розничная торговля; ремонт автотранспортных средств, } \\
\text { мотоциклов, бытовых изделий и предметов личного пользования }\end{array}$ & 20,9 & 18,2 & 16,9 & 12,1 & 10,7 & 10,6 \\
\hline Гостиницы и рестораны & 1,1 & 1,1 & 1,1 & 0,9 & 0,8 & 1,0 \\
\hline Транспорт и связь & 10,0 & 10,2 & 9,5 & 13,2 & 12,9 & 13,2 \\
\hline Финансовая деятельность & 0,7 & 0,6 & 0,5 & 0,2 & 0,3 & 0,2 \\
\hline Операции с недвижимым имуществом, аренда и предоставление услуг & 10,4 & 11,8 & 14,6 & 6,6 & 6,1 & 7,1 \\
\hline $\begin{array}{l}\text { Государственное управление и обеспечение военной безопасности; } \\
\text { обязательное социальное обеспечение }\end{array}$ & 4,6 & 5,6 & 4,9 & 8,4 & 8,2 & 6,7 \\
\hline Образование & 2,8 & 3,1 & 3,0 & 4,0 & 3,6 & 3,6 \\
\hline Здравоохранение и предоставление социальных услуг & 3,5 & 4,0 & 4,0 & 4,9 & 4,3 & 4,5 \\
\hline $\begin{array}{l}\text { Предоставление прочих коммунальных, социальных и персональных } \\
\text { услуг }\end{array}$ & 1,6 & 1,5 & 1,7 & 1,2 & 1,2 & 1,5 \\
\hline ВРП всего & 100 & 100 & 100 & 100 & 100 & 100 \\
\hline
\end{tabular}

Источник: рассчитано автором.

- повышение уровня жизни в регионе до среднероссийского;

- создание инфраструктуры и наращивание производственных мощностей с целью эксплуатации природно-ресурсного потенциала российского Дальнего Востока в интересах федерального центра.

Особое значение с точки зрения перспектив развития региона имел саммит АТЭС, проведенный Россией в 2012 году. При подготовке к саммиту во Владивостоке была реализована комплексная программа по строительству инфраструктурных объектов с целью превращения города в центр международного сотрудничества со странами АТР [9]. В ходе саммита руководством страны была озвучена позиция о готовности активно участвовать в социальноэкономическом развитии макрорегиона и обсуждать возможное международное сотрудничество по его освоению. Данное международное мероприятие стало катализатором для решения имеющихся экономических проблем. Его низкие инвестиционные результаты подчеркнули необходимость создания для этих малонаселенных и удаленных от центра страны территорий приоритетных экономических и социальных условий.

Основным индикатором развития Дальнего Востока был выбран объем привлеченного в макрорегион капитала. Акцент был сделан на привлечении крупного иностранного капитала.

Одним из инструментов привлечения инвестиций стало создание территорий опережающего социально-экономического развития (ТОСЭР) - экономических зон, ключевыми принципами которых выступают дерегулирование и масштабное налоговое стимулирование. Это, по большому счету, новая концепция «свободных (специальных)» экономических зон, успешно развивающихся в большинстве стран мира, но имеющих пока что неудачный опыт развития в России.

ТОСЭР стала новым механизмом поддержки инвесторов, реализующих проекты в таких приоритетных для Дальнего Востока видах экономической деятельности, как сельское хозяй- 
ство, рыболовство, транспортно-логистический комплекс, услуги, пищевая промышленность, добыча полезных ископаемых и туризм [14]. Благодаря мерам, направленным на развитие территорий, упрощенным административным процедурам и созданному налоговому режиму ТОР Дальнего Востока буквально за несколько лет стали лучшими по уровню комфорта бизнессреды, привлекательность их подтверждается интересом инвесторов (табл. 3).

Таблица 3

\section{Сравнение уровня комфорта бизнес-среды ТОР с показателями} по России и ведущим странам АТР

\begin{tabular}{|c|l|c|c|c|c|c|c|}
\hline $\begin{array}{c}\text { № п/ } \\
\text { п }\end{array}$ & \multicolumn{1}{|c|}{\begin{tabular}{c}
\multicolumn{1}{|l}{ Параметры бизнес-среды / } \\
количество дней
\end{tabular}} & РФ & $\begin{array}{c}\text { Южная } \\
\text { Корея }\end{array}$ & Китай & Сингапур & Япония & ТОР \\
\hline 1. & Регистрация предприятия & 26 & 4 & 127 & 6 & 89 & 3 \\
\hline 2. & Получение разрешения на строительство & 115 & 28 & 177 & 10 & 60 & 40 \\
\hline 3. & Регистрация собственности & 9 & 6,5 & 42 & 19 & 49 & 3 \\
\hline 4. & $\begin{array}{l}\text { Подключение к доступным мощностям } \\
\text { электроснабжения }\end{array}$ & 30 & 18 & 97 & 10 & 15 & 28 \\
\hline
\end{tabular}

Источник: составлено автором.

На начало 2017 года на территории Дальневосточного федерального округа были официально утверждены 14 территорий опережающего развития. Резидентам ТОР созданы оптимальные с учетом специфики макрорегиона и конкурентоспособные условия ведения бизнеса. Благодаря созданию «одного окна» на базе управляющей компании и совершенствованию процедур получения разрешений показатели административной нагрузки, сроки подключения к электроснабжению и получения разрешений на строительство в ТОР Дальнего Востока значительно ниже, чем в других регионах РФ и странах АТР.

Налоговый режим ТОР является механизмом с самыми длинными налоговыми каникулами в РФ и позволяет работать с минимальной налоговой нагрузкой на бизнес в период выхода проекта на прибыль и в течение последующих 5-10 лет [16]. Это дает возможность значительно сократить сроки реализации и окупаемости проекта, увеличить его доходность, а предусмотренный заявительный порядок возмещения НДС - существенно повысить оборачиваемость денежных средств капиталоемких проектов.

Основные требования, предъявляемые к инвесторам, для участия в ТОР заключаются в следующем: регистрация на территории опережающего развития, отсутствие филиалов и обособленных подразделений за пределами ТОР, отсутствие статуса резидента особой экономической зоны любого типа или участника регионального инвестиционного проекта, минимальный объем капитальных вложений в 500 млн руб.

Изначально в основу создания ТОР была заложена идея кластерного подхода, заключающегося в создании системы взаимосвязанных предприятий, взаимно дополняющих производственные процессы друг друга [1]. Базовым элементом такой территориальной системы выступает «якорное» предприятие или инвестор, обеспечивающий производство конечной продукции и определяющий тем самым основную специализацию ТОР.

Стоит отметить, что, по данным Реестра резидентов ТОР, размещенного на сайте Корпорации развития Дальнего Востока, не всегда можно определить их кластерную специализацию. Так, к примеру, в рамках ТОР «Хабаровск» на начало 2017 года ведут свою деятельность резиденты, занимающиеся производством сельскохозяйственной продукции, электрооборудования, химических веществ, продуктов металлургии и др. Можно предположить, что наблюдаемая несвязанность производств - результат простого стремления компаний воспользоваться назначенными преференциями.

Помимо создания и развития ТОР, ведется активная работа по запуску параллельных проектов, способных при определенных условиях ускорить развитие региона. Одним из таких проектов является «Свободный порт Владивосток» (СПВ). СПВ - территории муниципальных образований Приморского, Камчатского и Хабаровского краев, Сахалинской области и Чукотского автономного округа в пяти основных гаванях Дальнего Востока, пользующиеся особы- 
ми таможенными и налоговыми преференциями наряду с упрощенными административными процедурами [6]. Режим СПВ направлен на реализацию инфраструктурных проектов по строительству и реконструкции портовых терминалов, транспортно-логистических и складских комплексов, а также иных инвестиционных проектов, связанных с портовой деятельностью.

Резидентами СПВ могут стать российские юридические лица, в том числе с иностранным капиталом. Чтобы стать резидентом СПВ, необходимо соответствовать определенным требованиям: регистрация на территории СПВ, новый инвестиционный проект либо новый вид деятельности для уже существующей компании, минимальный объем инвестиций в 5 млн руб. [4].

В дополнение к установленным льготам с 1 января 2017 года вступил в силу федеральный закон, обеспечивающий уравнивание тарифов на электроэнергию на всей территории РФ. Благодаря этому тарифы на электроэнергию на Дальнем Востоке снизятся в среднем на $30 \%$.

Помимо создания благоприятных инвестиционных условий посредством предоставления различных льгот, для инвесторов предусмотрены специальные финансовые меры поддержки. Так, в 2015 году в Дальневосточном федеральном округе был запущен новый механизм предоставление инвесторам за счет федерального бюджета субсидий на компенсацию части затрат на создание и (или) реконструкцию объектов инфраструктуры, а также на технологическое присоединение к электрическим и газораспределительным сетям в целях реализации инвестиционных проектов. Размер субсидий из федерального бюджета на финансирование части затрат на инфраструктуру, необходимую для реализации проекта, напрямую зависит от размера частных инвестиций.

По состоянию на 2017 год на данный вид поддержки были поданы 54 заявки, из которых 14 поддержаны (табл. 4).

\section{Перечень проектов, получивших финансирование части затрат на создание инфраструктуры}

\begin{tabular}{|c|c|c|c|c|}
\hline $\begin{array}{c}\text { № ח/ } \\
\text { П }\end{array}$ & Проекты & Инвестор & \begin{tabular}{|c|}
$\begin{array}{c}\text { Частные инве- } \\
\text { стиции, млрд } \\
\text { руб. }\end{array}$ \\
\end{tabular} & $\begin{array}{c}\text { Бюджетные } \\
\text { субсидии, млрд } \\
\text { руб. } \\
\end{array}$ \\
\hline 1. & $\begin{array}{l}\text { Горно-обогатительный комплекс } \\
\text { «Инаглинский» }\end{array}$ & $\begin{array}{l}\text { Республика Саха (Якутия) / АО } \\
\text { «Инаглинский ГОК», ООО УК } \\
\text { «Колмар» }\end{array}$ & 23,9 & 0,6 \\
\hline 2. & $\begin{array}{l}\text { Транспортно-перегрузочный ком- } \\
\text { плекс в порту Ванино }\end{array}$ & $\begin{array}{l}\text { Хабаровский край / ООО «Саха } \\
\text { (Якутская) транспортная компа- } \\
\text { ния» }\end{array}$ & 19,6 & 3,3 \\
\hline 3. & $\begin{array}{l}\text { Проект развития угледобычи и угле- } \\
\text { обогащения }\end{array}$ & $\begin{array}{l}\text { Хабаровский край / ООО «СУЭК» / } \\
\text { ОАО «Ургалуголь» }\end{array}$ & 23,7 & 1,5 \\
\hline 4. & $\begin{array}{l}\text { Развитие золотодобычи в Се- } \\
\text { лемджинском районе }\end{array}$ & $\begin{array}{l}\text { Амурская область / ООО «ТЭМИ», } \\
\text { «Токурский рудник», «Албынский } \\
\text { рудник», «Маломырский рудник» }\end{array}$ & 36,5 & 5,5 \\
\hline 5. & Горно-металлургический комбинат & Камчатский край / ОАО «СиГМА» & 12,2 & 0,8 \\
\hline 6. & $\begin{array}{l}\text { 1-я очередь Таежного горно- } \\
\text { обогатительного комбината }\end{array}$ & $\begin{array}{l}\text { Республика Саха (Якутия) / ЗАО } \\
\text { «ГМК Тимир» }\end{array}$ & 12,2 & 1,6 \\
\hline 7. & Камчатский пивоваренный завод & \begin{tabular}{|l|} 
Камчатский край / ООО \\
«Камчатский пивоваренный завод»
\end{tabular} & 1,1 & 0,07 \\
\hline 8. & $\begin{array}{l}\text { Развитие свиноводства в Камчатском } \\
\text { крае }\end{array}$ & Камчатский край / ООО «Агротек» & 1,8 & 0,16 \\
\hline 9. & $\begin{array}{l}\text { Наталкинское золоторудное место- } \\
\text { рождение }\end{array}$ & $\begin{array}{l}\text { Магаданская область / АО «Рудник } \\
\text { имени Матросова» }\end{array}$ & 88,6 & 9,9 \\
\hline 10. & Алмазодобывающее предприятие & $\begin{array}{l}\text { Республика Саха (Якутия) / АК } \\
\text { «АЛРОСА» }\end{array}$ & 54,5 & 8,5 \\
\hline 11. & $\begin{array}{l}\text { Строительство и эксплуатация горно } \\
\text {-обогатительного комбината } \\
\text { «Тарын» на месторождении } \\
\text { «Дражное» }\end{array}$ & АО «Тарынская золоторудная» & 8,8 & 1,0 \\
\hline
\end{tabular}


СЕРИКОВ С.Г.

СПЕЦИФИКА ПРОСТРАНСТВЕННО-СТРУКТУРНЫХ ИЗМЕНЕНИЙ И ЭФФЕКТИВНОСТЬ НОВЫХ ИНСТРУМЕНТОВ ЭКОНОМИЧЕСКГО РАЗВИТИЯ РОССИЙСКОГО ДАЛЬНЕГО ВОСТОКА

\begin{tabular}{|c|c|c|c|c|}
\hline $\begin{array}{c}\text { № } \Pi / \\
\Pi\end{array}$ & Проекты & Инвестор & \begin{tabular}{|c|} 
Частные инве- \\
стиции, млрд \\
руб. \\
\end{tabular} & $\begin{array}{c}\text { Бюджетные } \\
\text { субсидии, млрд } \\
\text { руб. } \\
\end{array}$ \\
\hline 12. & $\begin{array}{l}\text { Организация производства строга- } \\
\text { ных и профилированных пиломате- } \\
\text { риалов в пос. Березовый }\end{array}$ & $\begin{array}{l}\text { Хабаровский край, Солнечный } \\
\text { район / ООО «Азия Лес» }\end{array}$ & 7,6 & 0,8 \\
\hline 13. & $\begin{array}{l}\text { Производственно-логистический } \\
\text { комплекс хранения разительного } \\
\text { сырья с оборудованием для подра- } \\
\text { ботки, сушки, перевалки зерна и } \\
\text { комплексный селекционно- } \\
\text { семеноводческий центр по производ- } \\
\text { ству семян сельскохозяйственных } \\
\text { культур }\end{array}$ & ООО «Амурагрокомплекс» & 1,6 & 0,2 \\
\hline 14. & $\begin{array}{l}\text { Строительство свиноводческого } \\
\text { комплекса }\end{array}$ & $\begin{array}{l}\text { Вяземский и Хабаровский район } \\
\text { Хабаровского края / ООО } \\
\text { «СКИФАГРО-ДВ» }\end{array}$ & 2,6 & 0,1 \\
\hline
\end{tabular}

Источник: составлено автором.

Таким образом, согласно данным табл. 4, на реализацию инвестиционных проектов было выделено 32 млрд руб. государственных инвестиций. По итогам реализации намеченных проектов планируется создание 11 тыс. рабочих мест.

Кроме того, на территории макрорегиона функционирует Фонд развития Дальнего Востока (ФРДВ). Цель ФРДВ - поиск, структурирование и реализация проектов в регионе, создание новых возможностей для привлечения инвестиций, оказание содействия региональным властям в подготовке и структурировании государственно-частных проектов [19]. До конца 2020 года ФРДВ планирует инвестировать средства не менее чем в 20 проектах общей стоимостью более 900 млрд руб., а также провести комплексную экспертизу не менее 25 проектов. Фонд также предоставляет инвестиционные кредиты под 5 \% годовых на реализацию инвестиционных проектов (табл. 5).

Таблииа 5

Проекты, получившие финансовую поддержку Фонда развития Дальнего Востока

\begin{tabular}{|c|l|c|c|c|c|}
\hline $\begin{array}{c}\text { № п/ } \\
\Pi\end{array}$ & Проект & Субъект РФ & $\begin{array}{c}\text { Общий объем инве- } \\
\text { стиций, млрд руб. }\end{array}$ & $\begin{array}{c}\text { Инвестиции } \\
\text { фонда, млрд } \\
\text { руб. }\end{array}$ & $\begin{array}{c}\text { Доля финансирования, } \\
\%\end{array}$ \\
\hline 1. & $\begin{array}{l}\text { Увеличение добычи угля на } \\
\text { Солнцевском месторожде- } \\
\text { нии }\end{array}$ & $\begin{array}{c}\text { Сахалинская } \\
\text { область }\end{array}$ & 45,1 & 2,8 & 16 \\
\hline 2. & $\begin{array}{l}\text { Развитие золотодобычи на } \\
\text { Камчатке }\end{array}$ & $\begin{array}{c}\text { Камчатский } \\
\text { край }\end{array}$ & 12,4 & 2 & 25 \\
\hline 3. & $\begin{array}{l}\text { Строительство трансгранич- } \\
\text { ного мостового перехода } \\
\text { через р. Амур }\end{array}$ & $\begin{array}{l}\text { Еврейская авто- } \\
\text { номная область }\end{array}$ & 10 & 2,5 & 33 \\
\hline 4. & $\begin{array}{l}\text { Строительство холодильно- } \\
\text { складского комплекса для } \\
\text { хранения и перевалки рыб- } \\
\text { ной продукции }\end{array}$ & $\begin{array}{c}\text { Приморский } \\
\text { край }\end{array}$ & 3,6 & 1,2 & 47 \\
\hline 5. & $\begin{array}{l}\text { Строительство транспортно- } \\
\text { логистического комплекса } \\
\text { «ухой порт» }\end{array}$ & $\begin{array}{c}\text { Приморский } \\
\text { край }\end{array}$ & 1,5 & 0,7 & $30 \%$ \\
\hline 6. & $\begin{array}{l}\text { Развитие современной ин- } \\
\text { фраструктуры по обраще- } \\
\text { нию с твердыми коммуналь- } \\
\text { ными отходами }\end{array}$ & $\begin{array}{c}\text { Сахалинская } \\
\text { область }\end{array}$ & 0,9 & 0,27 & 3 \\
\hline
\end{tabular}

Источник: составлено автором. 
Согласно данным табл. 5, на текущий момент фондом предоставлено 9,5 млрд руб. на реализацию 6 проектов.

Следует отметить, что процесс реализации новых инструментов развития на территории макрорегиона сталкивается с достаточно большим числом проблем.

Отдельно стоит затронуть земельный вопрос, являющийся краеугольным камнем любой бизнес-инициативы, затрагивающий резидентов ТОР, СПВ и получателей «дальневосточного гектара». Процедура получения земельного участка из-за сложных бюрократических процедур сильно увеличивает плановые сроки реализации бизнес-проектов. Согласно словам Ю. П. Трутнева, около 30 \% заявок, поданных на «дальневосточный гектар», отклоняется из-за отсутствия в предусмотренной информационной системе данных о правах третьих лиц на участки, границы которых не обозначены на карте и не поставлены на кадастровый учет, а также о землях Минобороны РФ.

Ориентация региональной политики на государственное регулирование привела к созданию управленческих институтов, нередко дублирующих друг друга. По состоянию на 2017 год в регионе ведут свою детальность: Министерство по развитию Дальнего Востока, Агентство по развитию человеческого капитала, Корпорация развития Дальнего Востока, Фонд развития Дальнего Востока, администрации ТОР и т. д. Остается низким уровень выполнения госпрограммы «Социально-экономическое развитие Дальнего Востока и Байкальского региона». По заключению комитета по региональной политике и проблемам Севера и Дальнего Востока отмечено, что в 2015 году выполнено 45,5 \% мероприятий, на которые было затрачено порядка $95 \%$ от запланированных расходов. В итоге было резко (до 51 млрд руб.) сокращено финансирование данной госпрограммы.

Не миновала развитие Дальнего Востока и коррупционная составляющая. По этой причине в 2017 году было расформировано Федеральное агентство по специальному строительству («Спецстрой»). Подразделение данной организации («Дальспецстрой») замечено в многочисленных финансовых скандалах, низком качестве выполнения строительных работ на космодроме «Восточный» в Амурской области и аэропорту «Петропавловск-Камчатский».

Сложившаяся на Дальнем Востоке производственная специализация характеризуется преобладанием в структуре ВРП отраслей сырьевой направленности [20]. В макрорегионе давно назрела необходимость повышения доли обрабатывающего сектора, но за последние годы проблема лишь усугубилась. Причиной усиления сырьевой направленности региона является продвижение на Дальнем Востоке нефтегазовых проектов, которые и обеспечивают положительную динамику роста ВРП. В 2012 году в результате мирового экономического кризиса обрушились мировые сырьевые и энергетические рынки, в результате экономика Дальнего Востока вошла в рецессию, и снова актуальной стала тема развития обрабатывающего производства.

Подводя итог всему вышесказанному, отметим, что за исследуемый период структура создаваемого в макрорегионе ВРП в разрезе входящих в него субъектов не претерпела значительных изменений. В динамике регион лишь усилил свою зависимость от сырьевых отраслей экономики. Кроме того, практика применения разработанных инструментов развития Дальнего Востока характеризуется поддержкой проектов исключительно сырьевой направленности. Таким образом, проводимая на Дальнем Востоке экономическая политика, при всех ее корректировках и нововведениях, скорее закрепляет, нежели видоизменяет, сложившуюся отраслевую структуру экономики региона. Задачи увеличения объемов международных потоков отодвигают в проводимой политике задачи качественной и производственной модернизации экономики региона.

По нашему мнению, процесс интеграции Дальнего Востока в АТР должен сопровождаться созданием новых рынков сбыта продукции. Это станет возможным за счет предложения новых наукоемких продуктов. Процесс «новый продукт - новая отрасль - новая специализация региона» должен быть запущен в рамках созданных ТОР. Для этого государству следует стимулировать развитие высокотехнологичных производств и не допускать попыток встраивания ТОР в уже сформированную систему сырьевой экономики. Выстроенная в итоге торговоинвестиционная периферия будет способствовать становлению Дальнего Востока в качестве одного из значимых игроков на рынке АТР. 
Литература

1. Андреева М. Ю., Вотинцева Л. И. Проектное финансирование - ключ к становлению иентров и осей развития территорий опережающего развития Дальнего Востока России // Финансы и кредит. 2017. - T. 23. - № 17 (737). - C. 1015-1032.

2. Гарусова Л. Н. Региональные аспекты современных международных отношений. АзиатскоТихоокеанский регион /Л. Н. Гарусова. - Владивосток: Изд-во ВГУЭС, 2012. - 228 с.

3. Графеев О. Е. Реализащия геополитического потенщиала Дальневосточного федерального округа Российской Федерации // Геополитика и безопасность. - 2015. - № 3 (31). - C. 120-125.

4. Жабыко Л. Л., Кузнецова Ю. С., Курбатова В. А. Свободный порт Владивосток // Экономика и управление: анализ тендениий и перспектив развития. - 2015. - № 22. - C. 48-53.

5. Заусаев В. К. Генеральная цель «Стратегии сочиально-экономического развития Дальнего Востока и Байкальского региона до 2025 г.»: концепџия или декларация? // ЭКО. - 2011. - № 6. - С. 167-178.

6. Красова Е. В., Ма И. Свободный порт Владивосток: условия развития, перспективы, риски // Экономические и сочиальные перемены: факты, тенденции, прогноз. - 2015. - № 6 (42). - С. 108-122.

7. Ларин В. Л. Стратегические приоритеть развития Тихоокеанской России // Мировая экономика и международные отношения. - 2015. - № 6. - С. 18-27.

8. Латкин А. П. Российский Дальний Восток: предпосылки и условия привлечения иностранных инвестиций: монография / А. П. Латкин, В. А. Казакова, Т. В. Евсеева. - Владивосток: Изд-во ВГУЭС, 2015. $-239 c$.

9. Локшин Г. М. АТЭС и саммит-2012: горизонть надежд для России // Проблемь Дальнего Востока. 2012. - № 1. - C. 17-31.

10. Минакир П. А. Развитие Дальнего Востока России в контексте будущего Северо-Восточной Азии: монография / Корейский институт международной экономической политики; Институт экономических исследований ДВО РАН; под ред. Ли Чжэ Ена, П. А. Минакира. - Хабаровск: ИЭИ ДВО РАН, 2017. $-108 c$.

11. Москвитина Н. А. Федеральные институты развития как механизм реализации региональной инвестииионной политики в России // Общественные финансы. - 2016. - № 2 (33). - С. 98-120.

12. Петрунина Ж. В. Современные ключевые направления интеграции Дальнего Востока России в АТР // Теория и практика общественного развития. - 2012. - № 10. - C. 165-168.

13. Рензин О. М. Региональная интеграция России в АТР и форум АТЭС // Пространственная экономика. - 2012. - № 2. - C. 161-164.

14. Сериков С. Г. Территория опережающего социально-экономического развития как инструмент достижения устойчивого сбалансированного развития Амурской области // Сибирская финансовая школа. - 2017. - № 5 (124). - C. 9-13.

15. Троянова Е. Н. Проблемы и перспективы соииально-экономического развития Дальнего Востока // Интерэкспо Гео-Сибирь. - 2013. - Т. 3. - № 1. - С. 23-26.

16. Швецов А. Н. «Точки роста» или «черные дыры»? (к вопросу об эффективности применения «зональных» инструментов госстимулирования экономической динамики территорий) // Российский экономический журнал. - 2016. - № 3. - С. 40-61.

17. Шмидт Ю. Д. Современные тенденџии развития экономики России и некоторые сравнительные оценки / Российский Дальний Восток и страны АТР: воспроизводство ресурсов и проблемы социальноэкономического развития: материаль Междунар. науч. конф. - Владивосток: ТГАЭУ, 2009. - С. 31-39. 18. Barkhordari S., Fattahi M. Reform of energy prices, energy intensity and technology: A case study of Iran (ARDL approach) // Energy Strategy Reviews. 2017. Vol. 18. P. 18-23.

19. Blagrave P. Vesperoni E. The implications of China's slowdown for international trade // Journal of Asian Economics. 2017. Vol. 18. P. 1-29.

20. Tsepelev O. A., Serikov S. G. Peculiarities of Regional Development and Industrial Specialization of the Far East of Russia // Journal of Applied Economic Sciences. 2017. T. 12. No. 5 (51). P. 1422-1432.

\section{References:}

1. Barkhordari S., Fattahi M. Reform of energy prices, energy intensity and technology: A case study of Iran (ARDL approach) // Energy Strategy Reviews. 2017. Vol. 18. P. 18-23.

2. Blagrave P., Vesperoni E. The implications of China's slowdown for international trade // Journal of Asian Economics. 2017. Vol. 18. P. 1-29.

3. Garusova L. N. Regional aspects of modern international relations. Asian-Pacific area // L. N. Garusova. Vladivostok: Publishing House of VSUES, 2012. 228 p.

4. Larin V. L. Strategic priorities of development of Pacific Russia // World economy and international relations. 2015. No. 6. P. 18-27.

5. Latkin A. P. The Russian Far East: Preconditions and Conditions for Attracting Foreign Investments: A Monograph / A. P. Latkin, V. A. Kazakova, T. V. Evseev. Vladivostok: Publishing house of VSUES, 2015. 239 p.

6. Minakir P. A. Development of the Far East of Russia in the context of the future of North-East Asia: monograph / Korean Institute of International Economic Policy; Institute of Economic Research, FEB RAS; Ed. Li Zhe Yen, P. A. Minakira. Khabarovsk: IEI FEB RAS, 2017. 108 p.

7. Petrunina J. V. Modern Key Areas for the Integration of the Russian Far East into the Asia-Pacific Region // Theory and Practice of Social Development. 2012. No. 10. P. 165-168.

8. Renzin O. M. Regional Integration of Russia into the Asia-Pacific Region and the APEC Forum // Spatial Economics. 2012. No. 2. P. 161-164. 
9. Schmidt Yu. D. Modern trends in the development of the Russian economy and some comparative assessments / The Russian Far East and the APR countries: the reproduction of resources and the problems of socioeconomic development: materials of the Intern. sci. Conf. Vladivostok: TGAEU, 2009. P. 31-39.

10. Grafeev O. E. Realization of the geopolitical potential of the Far Eastern Federal District of the Russian Federation // Geopolitics and Security. 2015. No. 3 (31). P. 120-125.

11. Troyanova E. N. Problems and prospects of social and economic development of the Far East // Interexpo Geo-Siberia. 2013. T. 3. No. 1. P. 23-26.

12. Zausaev V. K. The general goal of the "Strategy for the socio-economic development of the Far East and the Baikal region until 2025»: a concept or a declaration? // ECO. 2011. No. 6. P. 167-178.

13. Lokshin G. M. APEC and the 2012 Summit: Horizons of Hopes for Russia // Problems of the Far East. 2012. No. 1. P. 17-31.

14. Serikov S. G. Territory of advanced socio-economic development as an instrument to achieve sustainable balanced development of the Amur Region // Siberian Financial School. 2017. No. 5 (124). P. 9-13.

15. Shvetsov A. N. "Growth points"or Black holes"? (to the question of the effectiveness of the use of "zonal» instruments of state stimulation of the economic dynamics of territories) // The Russian Economic Journal. 2016. No. 3. P. 40-61.

16. Andreeva M. Yu. Votintseva L. I. Project financing is the key to the establishment of centers and axes for the development of the territories of advanced development of the Far East of Russia // Finance and credit. 2017. P. 23. No. 17 (737). P. 1015-1032.

17. Krasova E. V., Ma I. Free Port Vladivostok: development conditions, prospects, risks // Economic and social changes: facts, trends, forecast. 2015. No. 6 (42). P. 108-122.

18. Zhabyko L. L., Kuznetsova Yu. S., Kurbatova V. A. Free port of Vladivostok // Economics and management: analysis of trends and development prospects. 2015. No. 22. P. 48-53.

19. Moskvitina N. A. Federal Institutions of Development as a Mechanism for Implementing Regional Investment Policy in Russia // Public Finance. 2016. No. 2 (33). P. 98-120.

20. Tsepelev O. A., Serikov S. G. Peculiarities of Regional Development and Industrial Specialization of the Far East of Russia // Journal of Applied Economic Sciences. 2017. T. 12. No. 5 (51). P. 1422-1432. 